\title{
Investigation of activated sludge in different wastewater treatment systems
}

\author{
Thembinkosi Terrence Mcineka \\ University of Debrecen, Hungary
}

\begin{abstract}
.
The overall aim of this study was to investigate the activated sludge by using sludge activity (TTC) screening and microscopic method in determining the differences in the activated sludge of different wastewater treatment systems. The study presented the use of two methods to investigate the state of activated sludge in the wastewater. The first method was to use the Sludge activity (TTC) Screening method I to investigate the sludge activity respiration and the activity of the hydrogenase in the activated sludge. The method evaluated different setbacks and advantages that were incurred in the wastewater treatment plants. It encouraged the use of biological treatment of wastewater since it is the currently most used method in wastewater treatment systems worldwide. The biological wastewater treatment limited the naturally occurring bacteria in a very high concentration in the treatment works. Henceforth the need to understand the composition of activated sludge in the wastewater works remained vital and significant. The outcome of the microscopic investigation indicated that some samples did not meet the minimum acceptable sludge activity measurement range. It also indicated that Nocardia bacterial species were present in this system in large numbers, which indicated unfavorable conditions. This study emphasized the importance of biological treatment in wastewater treatment works.
\end{abstract}

Keywords: enzymatic activity; chemical treatment; anaerobic; aerobic; anoxic 


\section{Introduction}

Activated sludge system is the most extensively used biological wastewater treatment process. The process does not function without oxygen content (it is aerobic), it involves the incessant flow biological method for removal of soluble organic materials which are engrossed through the cell walls of the microorganisms and into the cells and conversion of these materials into more microorganisms, carbon dioxide, water, and energy (Beloti, V. et al.1999). In general, wastewater is generated from two major sources which are human sewage as well as processed waste from the industries (Davies, 2005). These wastes find their way to the environment through unlawful discharges into receiving waters and this leads to pollution in the waters and formation of water-borne diseases. The study aimed to investigate the state of activated sludge by using sludge activity (TTC) screening and microscopic. The two objectives were use these methods to determine state of an activated sludge from three wastewater treatment plants and also to use the removal efficiency method to calculate the significance of these methods.

\section{Methods}

The activated sludge was taken from three wastewater treatment plants (WWTP-1, WWTP2, and WWTP-3 WWTP-1 uses the Morden system technology in which the entire system is fully automated and can be easily controlled by remote control. The wastewater treatment plant has a capacity of $4000 \mathrm{PE}$ (population equivalent) and it has an average of $410 \mathrm{~m}^{3} /$ day of influent which comes from one settlement. The main objectives of the plant are the treatment of wastewater and removal of biological nitrogen and phosphorus. WWTP-2 has a capacity of $4000 \mathrm{PE}$ with an average inflow of $410 \mathrm{~m}^{3} /$ day that comes from three small settlements. This plant also has a biological tertiary treatment system. WWTP-3 had a larger capacity which was $6000 \mathrm{PE}$ and the inflow was coming from two settlements which were $620 \mathrm{~m}^{3} /$ day. This treatment plant had the oldest system of them all and also had tertiary treatment in which the main purpose was the removal of biological Nitrogen and Phosphorus.

\subsection{Sludge activity screening}

The activity of the sludge was determined by the HACH Lange method (Cuvette Test LCK 318) (Lukasse, 1999; Nesc, 2003. The sludge activity respiration in the activated sludge was determined with 2,3,5-triphenyl tetrazolium chloride (TTC). TT C was converted to red formazan by dehydrogenase enzyme activity. Formazan was extracted with ethanol and determined photometrically.

$$
\mathrm{C} 2=\mathrm{V} * \mathrm{TS}
$$

The inverted microscope (ck40 type) was used in the investigation and 50 ML sample was investigated. The investigation used only two types of magnifications (40x and 400x) for bigger and smaller organisms respectively. The removal efficiency was calculated to compare the effectiveness of these two methods 


\section{Results}

\subsection{Sludge Activity (TTC) Screening}

Table 1: displaying the results of Sludge Activity (TTC) Screening

\begin{tabular}{r|llll}
\hline Date of TTC & Sample number & $\begin{array}{l}\text { TTCResults }(\mu \mathrm{g} \\
\text { formazan) }\end{array}$ & $\begin{array}{c}\text { TSS }(\mathrm{g} / \mathrm{L}) \\
\text { Sludge Activity } \\
(\mu \mathrm{g} / \mathrm{mg} \text { s/udge total solids) }\end{array}$ \\
\hline 27.06 .18 & 7328 & 120.5 & 2.71 & 10.34 \\
27.06 .18 & 7331 & 93.5 & 5.31 & 4.09 \\
27.06 .18 & 7332 & 101 & 4.58 & 5.13 \\
27.06 .18 & 7367 & 86.5 & 4.69 & 4.29 \\
27.06 .18 & 7368 & 75.5 & 4.78 & 4.0 \\
\hline
\end{tabular}

Sample numbers 7331 and 7332 were taken from WWTP-1 in different aeration basins (Aeration basin 1 and 2). Sample numbers 7367 and 7368 were taken from WWTP-2 (Aeration basin 1 and 2), while sample number 7328 belonged to WWTP-3. The sludge activity of WWTP 1 and 2 was very similar, while WWTP 3 activity was at least twice as high.

Figure 1: displaying the occurrence of taxons in the wastewater sample of WWTP-1 aeration basin 1

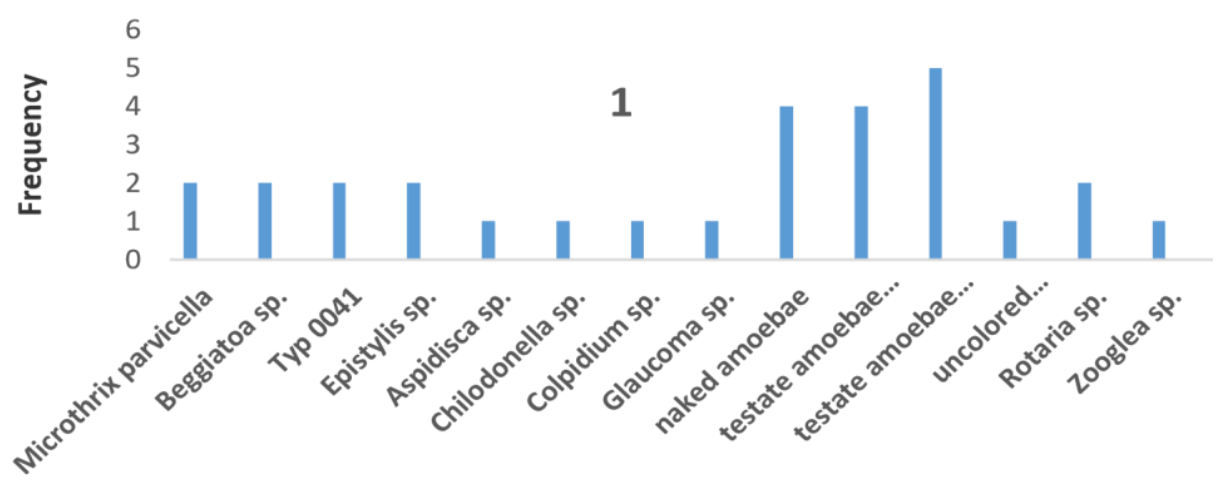

Identified Taxons

Wastewater

\section{Treatment Plant-1, Aeration Basin}

Figure 2: displaying the occurrence of taxons in the wastewater sample of WWTP-2 aeration basin 


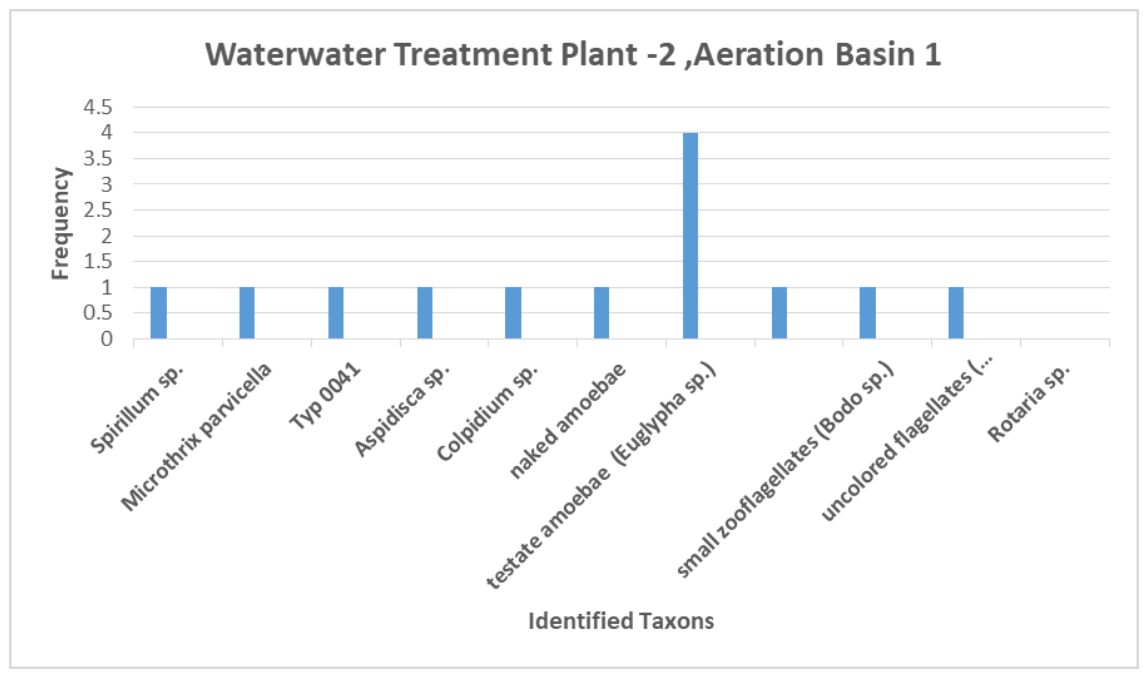

Figure 3: Displaying the occurrence of taxons in the wastewater sample of WWTP-3 aeration basin

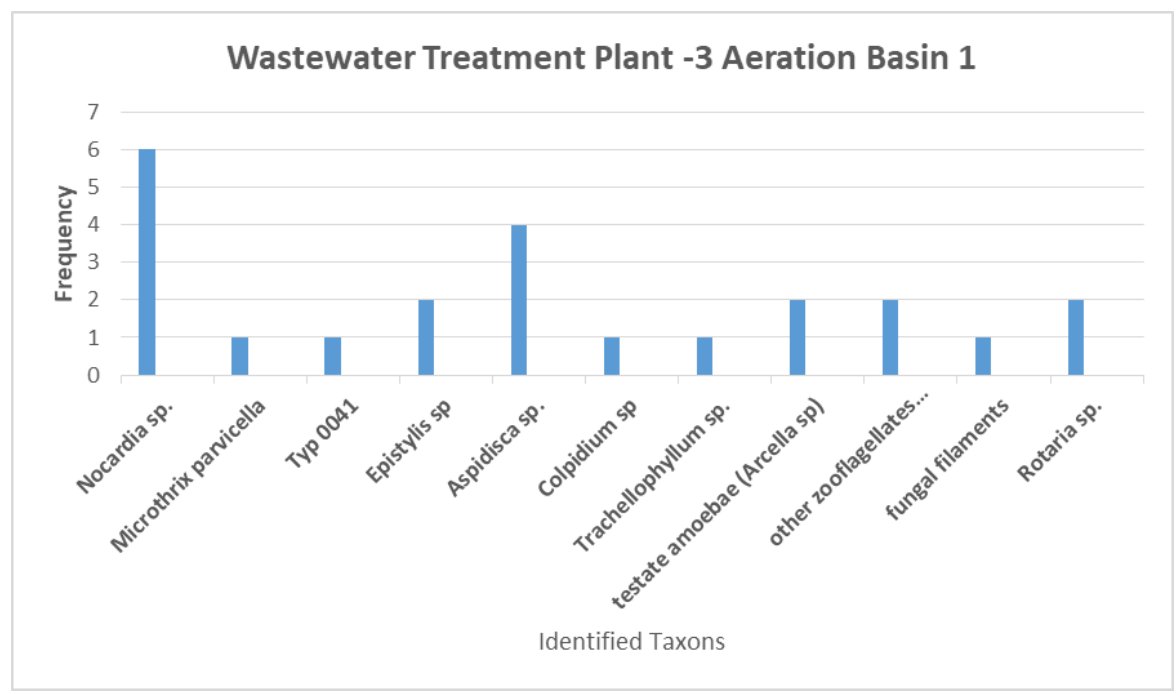

Amoeba indicated low loading condition (BOD) and good performance in the activated sludge in WWTP-1. Microthrix, parvicella, Beggiatoa sp., Typ 0041, Epistylis sp and Rotaria sp were among the second least organisms that were found in the activated sludge. The presence of Epystilis $s p$ indicated enough dissolved oxygen, it is also an indicator of sludge age, and they are typical in mature mud (Water Resources Division, 2017. WWTP-2 indicated the highest concentration of testate amobae (Euglypha sp.), while in WWTP-3 Nocardia $s p$ was dominant which indicated that the influent contained the high level of oil and grease, fats which affected the sludge age conditions (Davies, 2005). 
Table 2: showing results of the Removal Efficiency (\%) in all three wastewater treatment plants

\begin{tabular}{|c|c|c|c|c|c|}
\hline & $\begin{array}{r}R \\
E_{B O D}\end{array}$ & $\begin{array}{r}R E \\
C C O D\end{array}$ & $\underset{\text { otalN }}{\boldsymbol{R} \boldsymbol{E}_{\boldsymbol{t}}}$ & $\begin{array}{c}\boldsymbol{R E} \\
\text { totalP }\end{array}$ & $\begin{array}{r}\text { Aver } \\
\text { age RE }\end{array}$ \\
\hline & $\%$ & & & & \\
\hline $\begin{array}{l}\text { WWTP- } \\
1\end{array}$ & 99.3 & 88.9 & 93.6 & 96.2 & 94.5 \\
\hline $\begin{array}{l}\text { WWTP- } \\
2\end{array}$ & 99.2 & 92.3 & 86.6 & 65.8 & 86.0 \\
\hline $\begin{array}{l}\text { WWTP- } \\
3\end{array}$ & 97.5 & 91.9 & 38.5 & 63.9 & 73.0 \\
\hline
\end{tabular}

The average removal efficiency of the WWTP-1 and WWTP-2 systems was high. The WWTP1 system worked well for all parameters. In WWTP-2, total P removal efficiencies were lower, but the values of the other parameters were good. In WWTP-3, the total removal efficiency was only $73 \%$, which was mainly due to poor nitrogen removal.

\section{Conclusion and Discussions}

The results depicted that the sludge of WWTP-3 showed the highest activity, in spite of the lowest average removal efficiency. All three wastewater treatment plants had a wellbalanced number of micro-organisms. The aerobic bacteria was found more in the aeration basin since there was an abundance of oxygen and they were able to break down the organic materials found in the wastewater (Bhargava, 2016). The testate amoebas were dominant in the activated slude of WWTP- 1 and -2. They indicate low BOD loading and good performance. The presence of Nocardia bacteria in WWTP-3 indicated that there were problems in the treatment process since these bacteria are capable to form foam, and they create unfavourable and hazardous conditions in the treatment process (Johnson, McQuarrie and Shaw, 2004). The most modern WWTP-1 system showed the best removal efficiency in every respect. In WWTP-2, P removal efficiency was much lower than in WWTP-1. In WWTP-3, P removal is acceptable, but the efficiency of $\mathrm{N}$ removal was very low. The Sludge activity (TTC) screening method was able to provide information about the relative biochemical sludge activity on the basis of measurement of dehydrogenase enzyme activity of activated sludge sampled in three wastewater treatment plants. The use of an inverted microscopic analysis method was vital in the study since it was able to provide the information about the quantity and quality of micro-organisms that were found in the samples, the results provided information about the health and productivity of activated sludge in the treatment plants. All three methods were important in evaluating the operation of wastewater treatment systems. Each method provided information from a differrent perspective and together gave a more complete picture of how the systems work. The findings of this study added more value to the body of knowledge and helped in finding more information 
and solutions of solving water pollution related challenges and improve the water and wastewater quality of the effluents.

\section{Acknowledgment}

I would like to express my utter gratitude to my supervisor Magdolna Dr. K. Kiss and cosupervisor Ildiko Dr Czegeny for their constant support and leadership during my MSc study that lead to the formation of this paper. I would like to thank them for their patience, motivation and guidance that helped me in writing this paper. I could not have asked for a better advisors and mentors for my study.

\section{References}

[1] Beloti, V. et al. (1999) 'frequency of 2, 3, 5-triphenyltetrazolium chloride (ttc) nonreducing bacteria in pasteurized milk', pp. 137-140.

[2] Bhargava, A. (2016) 'Activated Sludge Treatment Process - Concept and System Design', 4(2), pp. 890-896.

[3] Davies, P. (2005) 'The biological basis of wastewater treatment', Strathkelvin Instruments Ltd. United Kingdom, p. 20. Available at: http://bartecbenke.nl/media/1000154/thebiologicalbasisofwastewatertreatment.pdf.

[4] Johnson, T. L., McQuarrie, J. P. and Shaw, A. R. (2004) 'Integrated Fixed-Film Activated Sludge (Ifas): the New Choice for Nitrogen Removal Upgrades in the United States', Proceedings of the Water Environment Federation, 2004(16), pp. 296-318.

[5] Lukasse, L. J. S. (1999) Control and Identification in Activated Sludge Processes (2014), pp. 4488-4498.

[6] Cisterna, P. (2017) 'Biological Treatment by Active Sludge with High Biomass Concentration at Laboratory Scale for Mixed Inflow of Sunflower Oil and Saccharose'.

[7] Eikelboom, D. H. (2000) 'Process control of activated sludge plants by microscopic investigation', p. 156. Available at: http://books.google.com/books?id=wE8C7SVySbMC.

[8] Tchobanoglous, G., Burton, F. L. and Stensel, H. D. (2003) McGraw-Hill Higher Education Library of Congress Cataloging-in-Publication Data. Water Resources Division (2017) 'Activated Sludge Process Control: Training Manual for Wastewater Treatment Plant Operators'. Available at: www.michigan.gov/deq.

[9] Urbain V., Block J.C. and Manem J. (1993). Bioflocculation in Activated Sludge: An Analytical Approach. Wat. Res.27 (5): 829-838.

[10] WDNR (2010) 'Introduction to Activated Sludge Study Guide Wisconsin Department of Natural Resources', (December). Available at: http://dnr.wi.gov. 